this uniform lower tax rate to a series of individual assessments, each uniformly increased by a constant multiplier, yields exactly the same amount of tax liability with respect to each assessment, disregarding any effect of tax rate limits, as that which would be obtained by extending against each original assessment the higher tax rate which would have resulted had the aggregate of the original assessments been divided into the same amount of tax levy. This would hold true no matter how the uniform multiplier had been derived and regardless of its relation to the assessments to which it might be applied.58 The application of any constant multiplier to each individual assessment will magnify in an absolute sense any disparity in individual assessments, but it will not change the proportionate liability of one assessment to another or to the county average. .7

The rationale of the Wasson Coal Co. case is thus equally applicable to real or personal property assessments. The assessment issue, in any case in which it is argued that an assessment, as equalized under the Butler Program machinery, is in excess of full fair cash value, reduces to a question of whether the original rather than the equalized assessment represents a fair valuation in relation to all other original assessments in the taxing district. It would thus appear that, had the Court of Appeals chosen to rule on the Butler Program in the Chicago Railways case, the disposition of the case should have been the same-an inquiry into the facts of the original assessment.

\title{
VOTING TRUSTS UNDER THE ILLINOIS BUSINESS CORPORATION ACT
}

Section 3 oa of the Illinois Business Corporation Act permits the use of voting trusts in the management of corporations, ${ }^{1}$ but limits the duration of such trusts

\footnotetext{
${ }^{56}$ It should be observed, however, that this identity of tax charges results only where all assessments have been equalized by the same constant multiplier. It does not, therefore, necessarily obtain in the case of a taxing district which overlaps two or more county boundaries or in the relative distribution of taxes as between state-assessed and locally assessed property. But, as has been observed, the Butler Program was designed to effect changes in just these instances by eliminating the variation in average assessment levels as between counties and as between locally assessed and state-assessed property.

${ }^{57}$ The Full-Value Assessment Program: An Analysis of the Butler Program, a report prepared by the Committee of the Ill. State's Att'ys Ass'n in collaboration with the Ill. Dept. of Rev., at 5 (1946).

1 The constitutionality of voting trusts in Illinois is not settled. Article XI, Section 3 of the Illinois Constitution requires that each stockholder have the right to vote for directors, and in Luthy v. Ream, 270 IIl. I7O, IIO N.E. 373 (19r5), the Illinois Supreme Court held that voting trusts separate stock ownership from corporate control and are thus repugnant to the constitutional provision. However, the Supreme Court in two subsequent cases distinguished Luthy v. Ream on the grounds that there is no separation of ownership from control where a corporation issues stock directly to voting trustees instead of to the stockholders who then confer them upon the trustees. Rittenberg v. Murnighan, 38 I Ill. 267, 44 N.E. 2d 9I3 (I942);
} 
to "a period of not to exceed ten years."' By providing a means for voting stock as a unit large enough to control a corporation, voting trusts are potentially both useful and harmful. They may assure the retention of expert management and provide stability demanded by prospective creditors, but they also weaken stockholder control over management. ${ }^{3}$ Section $30 a$ represents the legislative conclusion that voting trusts of limited duration are not so harmful as to justify restriction on freedom of contract.

Practical application of the section will require clarification of the effect and definition of an excessively long trust. The language of Section 3oa, legalizing trusts which do not exceed ten years, fails to specify whether an excessively long trust is to be invalidated entirely or only for the period beyond ten years. ${ }^{4}$ In resolving this ambiguity, the courts will be faced with a variety of clauses limiting trust durations. A trust of indefinite duration (such as one created for the life of A) will present a problem only if the courts decide entirely to invalidate overly long trusts. The statutory language may well permit the courts to uphold such a trust until it becomes certain that it will not actually terminate within the prescribed period. Under either view of the effect of excessive length, difficulties are raised by trusts which are limited to ten years or less but are renewable upon the happening of some condition. The simplest example is a trust to last for ten years unless the trustees, in their sole discretion, decide to extend it. Since this would give the trustees and those they actually represent complete control over the trust's duration, this trust should be treated like one created to last indefinitely. Many trust agreements subject the trustees' determination to ratification by the beneficiaries, requiring either affirmative approval by a certain percentage of the certificate holders or else the absence of a specific percentage of dissents. The effectiveness of this control is questionable

Babcock v. Chicago Rys. Co., 325 Ill. I6, I55 N.E. 773 (I927). The tenuous nature of this distinction indicates that the court may overrule Luthy v. Ream in an appropriate future case. The Validity of Stockholders' Voting Agreements in Illinois, 3 Univ. Chi. L. Rev. 640 (1936).

2 Ill. Rev. Stat. (I947) c. 32, § I57.30a provides, "Any number of shareholders of a corporation may create a voting trust for the purpose of conferring upon a trustee or trustees the nght to vote or otherwise represent their shares, for a period of not to exceed ten years, by entering into a written voting trust agreement specifying the terms and conditions of the voting trust, and by transferring their shares to such trustee or trustees for the purposes of the agreement."

${ }^{3}$ The control which shareholders surrender by entering into a voting trust is the right to elect orvote against directors and to veto various extraordinary transactions. Ballantine, Voting Trusts, Their Abuses and Regulation, 2x Tex. L. Rev. I39 (1942). Realistically, the surrender of this right in large corporations is not a serious loss. Berle and Means, The Modern Corporation and Private Property, c. v. (I947).

4 There is authority for making the choice of the alternatives depend on the nature of the law prior to the enactment of a voting trust limita tion. If voting trusts were valid at common law, then the effect of their exceeding the statutory period should be to cut down the duration to the proper length. If they were invalid independently of the statute, then their exceeding it should invalidate them entirely. 38 Col. L. Rev. 508 (r938), noting Perry v. MissouriKansas Pipe Line Co., 22 Del. Ch. 33, r9x Atl. 823 (1937). This approach would be difficult in Illinois where the validity of voting trusts has never been entirely certain. 
in view of the familiar apathy of stockholders in corporate voting. Thus an agreement permitting the trustees to extend unless 95 per cent of the beneficiaries object within a limited time would in practice be identical with a provision for extension based on the trustees' sole discretion. Similarly, where ratification is by affirmative approval the trustees can always count on the tendency of stockholders to go along with management. Requirements for a lower percentage of objectors or a higher proportion of affirmations may furnish a more realistic basis for beneficiary ratification. But the statute's ten-year limitation is not so phrased that the courts can vary its applicability according to the degree of control the beneficiaries have over the trustees. Although it is questionable whether the courts will hold limited but renewable trusts void ab initio, it seems likely that extensions will be held invalid.

Nothing in the wording of the statute, however, prevents some or all of the beneficiaries from creating a new trust on the expiration date of the old. ${ }^{5}$ And in many cases, instead of going through the formality of regaining their shares and again conferring them upon trustees, the beneficiaries who want a new trust may agree to extend the old one. Whether the courts will construe such an act of extension as equivalent to an act creating a new trust depends on the nature of the trust agreement's requirements for extension. If the trustees may extend subject to ratification by the beneficiaries' failure to object, permitting an extension would seem contrary to the statutory language and policy. For recognizing a duty of the beneficiaries to speak would give legal significance to the trust agreement and the relationships created thereby for a period beyond ten years. Where affirmative votes are required, the assenters have manifested a desire to have trustees continue to vote their shares. However, in Russ $v$. Blair, ${ }^{6}$ where an extension of a voting trust not subject to Section $30 a$ was held contrary to the trust agreement, the Illinois Supreme Court did not consider whether the assenters' affirmative votes could create a new trust as to them alone. And in consolidating this case with another in which an extension was based on the absence of dissents, ${ }^{7}$ the court failed to distinguish the situations.

By contrast, the concurring opinion in the Ohio case of Bechtel v. Rorick ${ }^{8}$ would only give effect to a purported extension by binding the assenting beneficiaries to a new trust. Further illustrating this approach, a Delaware statute which limits the duration of voting trusts contains a provision permitting assenting beneficiaries to continue a trust. ${ }^{9}$ An objection to the Delaware and Ohio viewpoint is that an assenter may not want to participate in a new or

\footnotetext{
5 The statute limits only the duration of a trust, not the shareholders' right to create it. "Any number of shareholders of a corporation may create a voting trust ... for a period of not to exceed ten years. ..." III. Rev. Stat. (I947) c. 32, \& I57.30a.

${ }^{6} 330$ IIl. App. 57 7 , 7 N.E. 2d 838 (1947).

' Olson v. Rosseter, 399 MIl. 232, 77 N.E. 2d 652 (1948).

865 Obio App. 455, 464, 30 N.E. 2d 45I, 455 (1939).

$\checkmark$ Del. Rev. Code (x935) \& 2050.
} 
extended trust unless it is likely to retain corporate voting control. The courts can remedy this difficulty by permitting the beneficiary to revoke if the trust does not maintain formal control. Or perhaps, in view of the occasional need for extraordinary majorities in ratifying corporate acts, the courts should not recognize a new trust unless the extension solicitations have expressly warned the beneficiaries of this consequence.

A more serious problem is that assents to an extension may result from a mistaken approval of the trustees' conduct by misled or poorly informed shareholders. When the voting trustees seek approval of an extension, they are under a fiduciary duty to make full disclosure of material facts to the certificate holders. ${ }^{10}$ However, the protection thus afforded cannot always be relied upon. If some of the beneficiaries rather than the trustees organize an extension, there may be no duty to disclose. ${ }^{11}$ Again, enforcement of the duty depends on the alertness of the beneficiaries and their willingness to undertake litigation. Finally, there are no definitive cases setting forth the substantive requirements for full disclosure in connection with extensions. ${ }^{12}$ To remedy this, the legislature could adopt full disclosure requirements ${ }^{13}$ and possibly set up an administrative agency to enforce them. Yet the disclosure problems in voting trust extensions are neither so unique nor so difficult that the legislature would be justified in singling out this area of the law for special treatment.

The analysis of Section $30 a$ is incomplete without reference to a recent Illinois case. In Plast v. Metropolitan Trust Co., ${ }^{14}$ which involved a business trust, the trust agreement required termination "in any event" within ten years, and it gave the trustees a power of sale. Before the expiration of the period, the trustees organized and took control of a corporation which was to "purchase" the trust property, exchanging one share of its stock and one of its income bonds for each certificate of interest in the old trust. The stock, however, was to be deposited in a voting trust under unchanged control.

10 Olson v. Rosseter, 330 Ill. App. 304, 7I N.E. 2d 556 (I947); Russ v. Blair, 330 Ill. App. 57I, 7 I N.E. 2d 838 (x947); see Shapiro v. Chicago Title \& Trust Co., 328 Ill. App. 650, 66 N.E. $2 \mathrm{~d} 73 \mathrm{I}$ (I946).

11 The Illinois Appellate Court has held that the beneficiaries of a voting trust are not in a fiduciary relationship with each other and owe each other no duty of disclosure in self-dealing. Krensky v. De Swarte, 335 Ill. App. 435,82 N.E. 2d I68 (I948). If applied to voting trust extensions, this doctrine would permit the trustees to evade their disclosure duties by secretly inducing a beneficiary to organize the extension. Such collaboration, however, is ordinarily a breach of the trust duties of both the trustee and the beneficiary. I Bogert, Trusts and Trustees $\S x_{9 I}\left(x_{935}\right)$. The Krensky case should either be overruled or held inapplicable to extensions.

12 The Illinois cases have recognized a duty to disclose but have not defined the disclosure necessary for extensions. Cases cited note II supra.

${ }^{13}$ The legislative definition might require information of the following matters: (I) revocability of the trust, (2) parties whom the trustees or other solicitors actually represent as agents, (3) the corporate interest of the trustees and other key persons, (4) compensation of the trustees, and ( 5 ) financial statements.

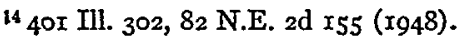


In approving this deal as a "sale" within the meaning of the agreement, a majority in the Illinois Supreme Court ignored the transaction's manifest purpose -continuation of control in the hands of the same trustees. ${ }^{15}$ Since the provision for termination in any event within ten years is analagous to Section 3oa's ten-year limit, the Supreme Court's failure to invalidate the arrangements of the Plast case sets up spurious sales as the pattern for circumventing the statutory prohibition. However, a greater awareness of the actual objectives of such transactions might result in rejection of the Plast case. It could, moreover, be distinguished from cases under Section $30 a$ because its time limitation was contractual.

\section{AN AMERICAN LEGAL DILEMMA-PROOF OF DISCRIMINATION}

The control of discrimination through legal sanctions is a two-fold process: (I) the enactment of anti-discrimination measures; (2) the enforcement of these measures. While in the past primary emphasis has been given the former, with the passage of anti-discrimination laws in a growing number of states, the enforcement factor is of an immediate and growing importance. ${ }^{1}$ Essential to the enforcement process is proof of discrimination in individual cases. It may well be that in a large sense the success or failure of combating discrimination through legal devices will ultimately depend upon the evidentiary proof which can be achieved in individual cases.

While effective enforcement demands proof of discrimination in individual cases, that an act has been discriminatory is not in all cases susceptible of clear and certain demonstration. Thus if the requirements of proof are made too rigorous, effective enforcement will not be achieved. On the other hand, lax requirements of proof may result in erroneous findings of discrimination and in unjustified limitations of free choice. At both the enactment and the enforcement stages in the legal control of discrimination the ideal of equality, upon which anti-discrimination measures are based, is in conflict with the equally fundamental ideal of free choice. When an anti-discrimination law is enacted it has been decided that the societal demands of equality justify a certain limitation on free choice. But that limitation of free choice which results from an erroneous finding of discrimination is not justified by the legislation. ${ }^{2}$ Because

${ }^{15}$ Contrast the dissenting opinion of Judge Gunn, ibid., at $3^{1} 7,162$.

I For example FEP Acts: N.Y. Executive Law (McKinney, Supp. 1948) c. 23, \$§ 125-36; Conn. Gen. Stat. (I949) $\$ \$ 7400-7$; I Mass. Ann. Laws (Supp. I948) c. 6, $\$ 56 ;$ N.J. Rev. Stat. (Supp. 1937) tit. 18, c. 25, \$§ I-28; N.M. S. 45, Igth Assemb., Reg. Sess. (March I7, I949); R.I. H. 539, Gen. Assemb. 1949, Reg. Sess. (April I, I949); Ore. S. 235, 45th Assemb., Reg Sess. (March 21, 1949); Wash. S. I2, 21st Assemb., Reg. Sess. (March I9, I949). Housing: III.

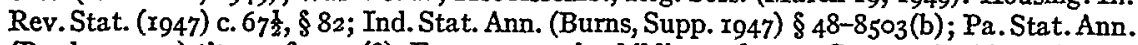
(Purdon, 1949) tit. 35, § I 7 II (8). For an extensive bibliography see Graves, Anti-Discrimination Legislation in the American States (r948).

2 The limitation of free choice and the dangers of an erroneous judgment are not, of course, unique with anti-discrimination measures. The outlawing of any action will serve to limit free 